\title{
Epilepsziás páciens protetikai rehabilitációja BioHpp alkalmazásával
}

\author{
DR. NÉMETH FANNI, DR. HERMANN PÉTER
}

Terápiarezisztens epilepsziás páciensünk anamnézisében több rohamforma is előfordult, így évente többször grand mal, mely tudatvesztéssel is együtt jár, absence roham, myoklónusos roham, és komplex parciális roham. A rohamok testszerte számos sérülést okoztak, így clavicula-törést, orbita alap törést és vállficamot, valamint a felső részleges fémlemezes fogpótlás akrilát múínyének és múfogainak törését, ezért a konvencionális tervezésű fogpótlás használhatatlanná vált. A BioHpp anyaga rugalmasabb a hagyományos fémlemezek anyagaihoz képest. Az ebből készült kivehető lemezes fogpótlását páciensünk 1,5 éve panaszmentesen viseli. Kevésbé törékeny fizikai tulajdonságai miatt a BioHpp használatának új indikációs területét jelentené az epilepsziás páciensek kivehető fogpótlással történő ellátása.

Kulcsszavak: epilepszia, BioHpp, GM rohamok.

\section{Bevezetés}

Az epilepszia krónikus agyi múködészavar különböző etiológiával, melyet visszatérő rohamok jellemeznek. A neurológiailag kompromittált betegek, így az epilepsziás betegek szájüregi állapota sok tekintetben elma-rad az egészséges populációhoz képest, ritkábban járnak fogorvoshoz. [1, 2] A maradék fogazat állapotát mutató DMF-T index (hiányzó, szuvas és tömött fogak aránya) szignifikánsan rosszabbnak bizonyult, és a betegség súlyosságával romlott. A parodoncium állapotát jelző PPD (periodontal pocet depth) szondázási mélység, és CAL (clinical attachment loss) klinikai tapadásveszteség - mely az íny-recesszió és a szondázási mélység öszszege - szignifikánsan romló tendenciát mutatott a betegség súlyosbodásával, ami a rossz szájhigiénia következménye is. $[3,4] \mathrm{Az}$ iniciatíva hiánya és az izoláció miatt az epilepsziás páciensek fogpótlással való ellátottsága gyengébb volt az egészséges populációhoz képest. A generalizált tónusos-klónusos rohamok gyakran vezetnek szájüregi sérülésekhez, a maradék fogakból, vagy fogpótlásokból letört darabokat a páciens könnyen aspirálhatja. [3] Buck és munkatársainak vizsgálatai szerint a rohamok okozta sérülések $24 \%$-nál a fej-nyak régió és a maradék fogazat is sérül, mely együtt jár a fogak elvesztésével. [5, 6, 7] Az epilepsziás páciensek adekvát fogászati ellátására osztályozási rendszert és terápiás útmutatót dolgoztunk ki. [3, 4] Az epilepsziás páciensek implantátummal történő ellátása tekintetében a fogorvos-társadalom megosztott. A protetikai ellátás nem történhet minden esetben implantátumok segítségével, financiális okok, a gyakori nagy rohamok okozta kognitív és mentális képességek folyamatos romlása és a rossz szájhigiénés viszonyok miatt, így minden eset individuális elbírálást igényel. [8]

Tapasztalataink szerint a nagyrohamok miatt a konvencionális kivehető fogpótlásról a kapcsok, a múíny és a müfogak gyakran letörnek, ezért a rágóképesség megszűnik, esztétikai funkcióját, valamit a hangképzésben játszott szerepét sem tölti be tovább a fogmü. $[3,4]$

A BioHpp ${ }^{\circledR}$ (Biocompatible high performance polymer; Bredent, Senden, Németország) használatának új indikációs területét jelentené az epilepsziás páciensek kivehető fogpótlással történő ellátá sa, mert a CAD/CAM technológiával egy darabból kimart fogpótlás jobb mechanikai tulajdonságai, kiemelten rugalmasabb és kevésbé törékeny mivolta csökkenti a törés veszélyét. Szükség esetén könnyebben javítható a kisebb letört darabok miatt, mint a kobalt-króm fémlemez. Míg a müíny és a múfogak csak mechanikai úton kapcsolódnak a fémlemezhez, addig a BioHpp esetében mechanikai és kémiai úton is, mert a Visio.Link (Bredent, Senden, Németország) kötésjavító képes kötést létrehozni a Visio.Lign leplező-termékek (leplező héjak, műfogak, kompozit) (Bredent, Senden, Németország) és a BioHpp jellegú vázanyagok között. [9, 10, 11] A BioHpp fogpótlás esztétikai szempontból megfelelő, fogszínú anyag. A speciális kerámiaszemcsékkel erősített, termoplasztikus, részkristályos BioHpp, alapja a PEEK (polyéter-éter-keton), eléri a protetikai ellátáshoz szükséges mechanikai szilárdságot. A PEEK-et 1990 óta bioinert, sterilizálható gyógyászati implantátum alapanyagként (pl. gerincgyógyászatban és csípőízületeknél) sikerrel alkalmazzák, eddig nem mutatkozott klinikailag releváns anyagfáradás. A fogászati fémötvözetekre allergiás páciensek, és a fémmentes pótlást egyéb okokból 
előnyben részesítő páciensek számára is alternatív terápiás megoldást jelent. $[9,10,11]$

A BioHpp biokompatibilis, jól tisztítható, reziliens, sokkelnyelő, nem abradálja a maradék fogakat és kopásálló. Keménysége 294 N/mm2, elaszticitási modulusa 4200$4800 \mathrm{MPa}$ ezzel a csontéhoz hasonló. Hajlítószilárdsága magas, 180-185 MPa, csekély a hővezetése, jól polírozható így nem károsítja a parodontiumot. Indikációs területe széles, csapos műcsonkok, koronák, hidak, teleszkóp- vagy stéges rendszerek, csavarozott implantációs pótlások készítésére egyaránt alkalmas. [9, 10,11]

\section{Esetismertetés}

\section{Általános anamnézis}

65 éves férfi páciensünk 4 éves kora óta temporális lebenyből induló, generalizált, terápiarezisztens epilepsziában szenved. Anamnézisében több rohamforma is elöfordul, így pillanatnyi kihagyás (absence), myoklónusos roham, komplex parciális roham és évente többször tudatvesztéssel is együtt járó grand mal nagyroham. Emiatt testszerte több sérülése is volt (clavicula-törés, orbita alap törés, vállficam). Jelenleg szedett gyógyszerei: Topamax $50 \mathrm{mg} 2 \times 1$, Neurotop $600 \mathrm{mg} \mathrm{1/2-0-1}$. A kezelések alatt jól kooperált, de kognitív deficittel rendelkezett. Nem inzulindependens, I. típusú diabetes mellitusa volt.

A fentiek miatt páciensünket a sztomatológiai elláthatóság szempontjából a III. csoportba soroltuk [3], a fogpótlás tervezésénél szigorú megkötéseket szabtunk. $A$ preparált csonkokat kémiai úton védtük - Bifluoridos ecsetelés, (Bifluorid 10, Voco GmbH Cuxhaven, Germany) -, mert ideiglenes akrilátkoronák készítése kontraindikált azok törékenysége, és a tört darabok aspirációjának veszélye miatt. Részleges kivehető fogpótlás tervezése esetén a kapocselhorgonyzás és akrilát alaplemez készítése szintén fentiek miatt kontraindikált, ezért a felső állcsonton a szubtotális foghiányt, a fémhez hasonló keménységű BioHpp teleszkópos elhorgonyzású és alaplemezú fogpótlással láttuk el. Az alsó állcsonton, a hídpótlások tervezése során, az egyébként szükségeshez képest, több segédpillért vontunk be, azaz növeltük a kiterjesztés mértékét, a grand mal rohamok okozta többletterhelés kompenzálására. A hídváz konnektor részeit megvastagítottuk. [3, 4]

\section{Fogászati anamnézis, kezelési terv}

A páciens szájhigiéniája rossz volt, a Greene-Vermillionféle Oral Higienes Index értéke, annak mindkét komponense, a plakkindex (debris) DI-S és a fogkőindex (calculus) Cl-S értéke is „3” volt. [12] A protetikai ellátás előtt supra- és subgingivális depurálást, szájhigiénés instruálást, motiválást végeztünk. Felső, kivehető, öntött kapocs elhorgonyzású, fém alaplemezű fogpótlása körülbelül 3 éve készült, de a grand mal rohamok miatt, az akrilát müíny és a múfogak a front régióban letörtek, így a pótlás használhatatlanná vált. (1. kép)

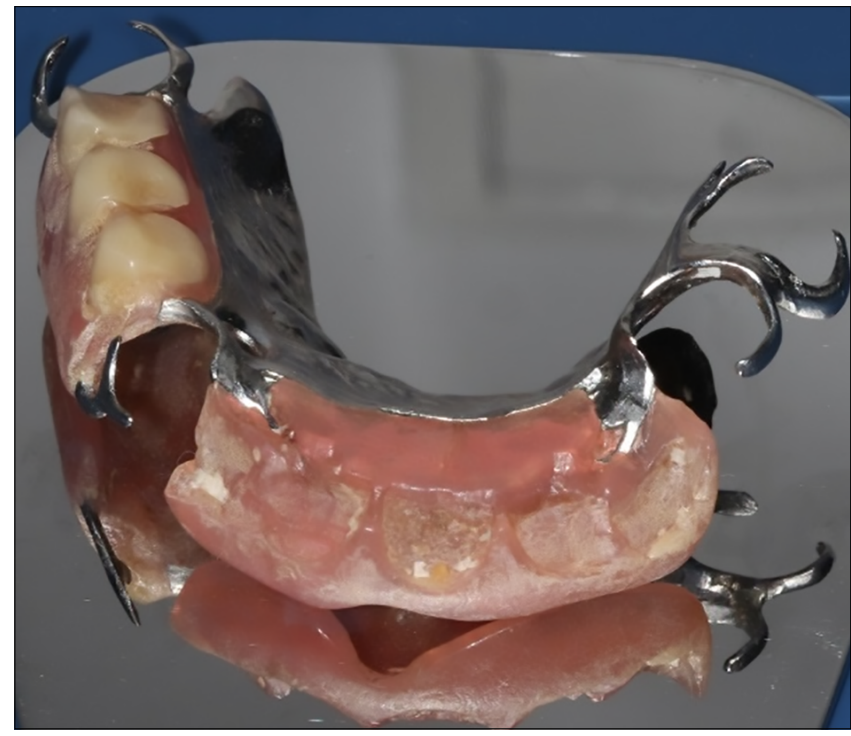

1. kép: A felső fém alaplemezes, öntött kapocs elhorgonyzású, részleges, kivehető fogpótlás front területéről az akrilát múfogak és műíny a nagyrohamok miatt kitörött, így a fogpótlás használhatatlanná vált.

A Fábián és Fejérdy-féle foghiány beosztás szerint a felső állcsonton $2 \mathrm{~A} / 1$, az alsó állcsonton $1 \mathrm{~B}$ osztályba tartozott a foghiány. A felső állcsontra teleszkópos elhorgonyzású, fedőlemezes (overdenture) fogpótlást terveztünk, kedvező fizikai tulajdonságai miatt fenesztrált BioHpp alaplemezzel, cilindrokónuszos BioHpp primer és szekunder teleszkópokkal [17, 27], valamint 14 BioHpp, speciális kompozitleplezésú múfoggal. Az alsó állcsontra egy teljes fogívre kiterjedő, kiterjesztett hídpótlást terveztünk két részben; egy 11 és egy 3 tagú hídpótlást $\mathrm{CoCr}$ ötvözetből kompozitleplezéssel. Leplezett horgonykoronák a 11 tagú hídnál: 48, 43, 42, 41, 31, 32, 33; a leplezett hézagfogak: 47, 46, 45, 44 fogak voltak. A 3 tagú hídpótlás leplezett horgonykoronái: 34 , 35; a leplezett hézagfog a 36 volt. A 35-ös fogba $\mathrm{CoCr}$ ötvözetből készült öntött csonkkiegészítő csapos műcsonkot terveztünk.

\section{Kezelés menete}

A kezelést a felső állcsont ellátásával kezdtük. A tanulmányi lenyomatok elkészítése után a mintára (IV. Begostone Plus, Bego, Brema, Németország) berajzoltuk a felső egyéni kanál határait, és clear akrilát Meliodent (Heraus Kulzer, Hanau, Németország) egyéni kanalat kértünk a laboratóriumtól. A pillérfogak előkészítése után az egyéni kanál segítségével precíziós szituációs lenyomatot vettünk Thixoflex M-(Zhermack Sga, Badia Polisina, Ravigo, Olaszország). A kiöntött minta beszkennelése után digitálisan megterveztük a BioHpp primer cilindrokónuszos teleszkópokat (2. kép) A frézgépbe (Roland, Japán) behelyeztük a BioHpp tömböt, és kimartuk a primer teleszkópokat. (3. kép, 4 a kép, 4.b kép) A primer teleszkópok próbája után funkciósszituációs lenyomatot vettünk cinkoxid-eugenol (SS White 


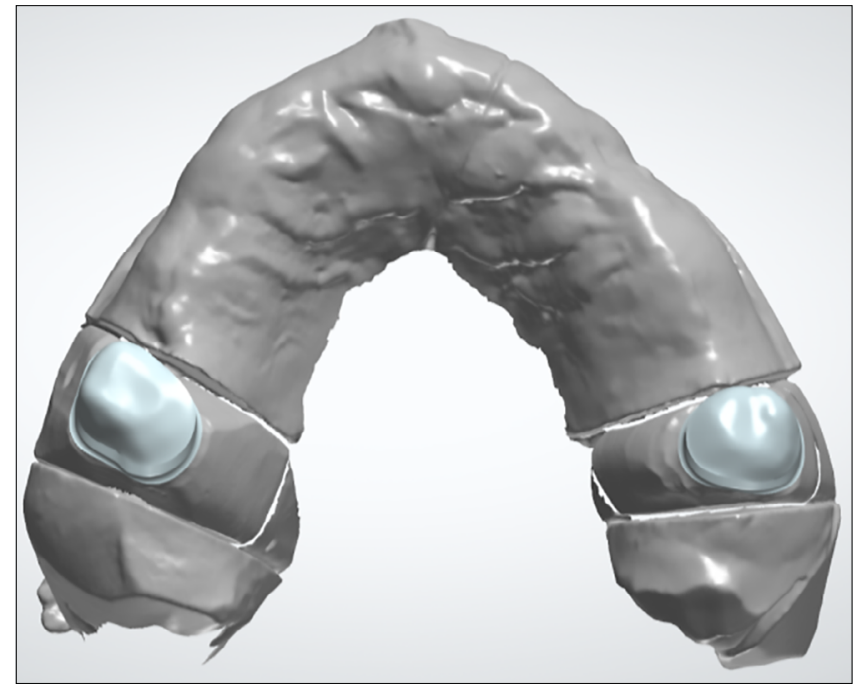

2. kép: Felső beszkennelt minta a tervezett BioHpp primer teleszkópokkal.

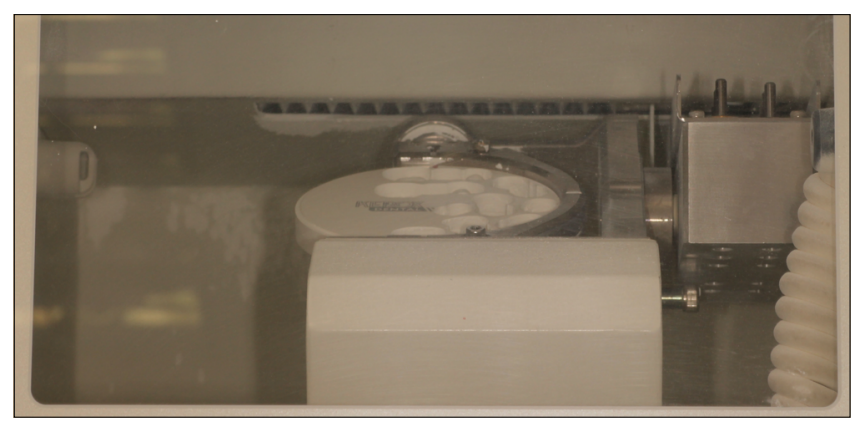

3. kép: A BioHpp tömb frézelésére alkalmas frézgép (Roland Germany)

Group, Gloucester, Egyesült Királyság) lenyomatanyaggal. (5. kép, 6. kép) A keménygipsz mintára a laboratórium elkészítette külön az alaplemez és külön a szekunder teleszkópok viaszmintázatát, melyet szkennelés után adott méretű BioHpp tömbből martak ki. A fenesztrált formára azért volt szükség, mert a tömb mérete csak erre adott lehetőséget, de teljes alaplemez tervezése a kedvező fizikai tulajdonságok miatt amúgy sem volt szükséges. (7. kép) A szekunder teleszkópokat az alaplemezbe Visio.Link speciális ragasztó anyaggal rögzítettük. (8. kép) A szekunder teleszkópok és a BioHpp alaplemez próbája után arcíves regisztráció, centrális reláció meghatározás és fogszínválasztás következett Vita 3D Master (Vita GmbH, Essen, Németország) fogszínkulccsal. A próbafogsor ellenőrzése és a fogpróba után az elkészült fogpótlás átadásra került. (9. kép, 10. kép) A primer teleszkópokat a laboratóriumban Visio.Link primerrel történt előkezelés után, Maxcem Elite (Kerr Corporation, Detroit, USA) self-adhesive resin cementtel rögzítettük a szájban.

Az alsó állcsont ellátását a 35-ös fogba tervezett öntött csonkkiegészítő csapos múcsonk elkészítésével kezdtük. Ezt követően a pillérfogak előkészítése után
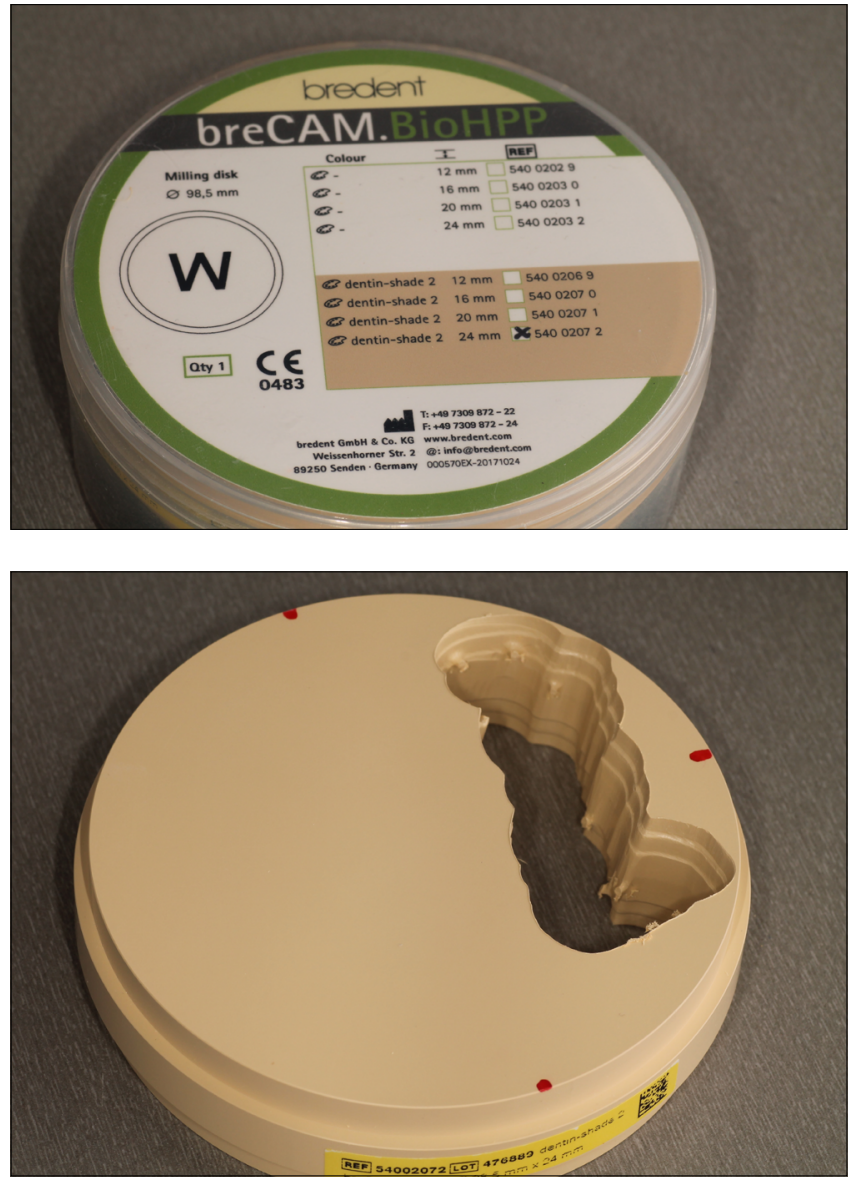

4.a, b kép: A Bredent cég által forgalmazott BioHpp tömb.

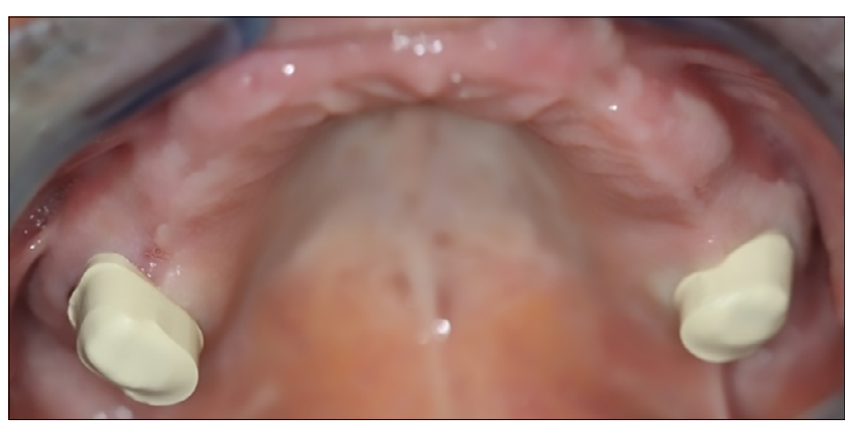

5. kép: A BioHpp tömbből kifrézelt primer teleszkópok próbája szájban.

kétfázisú, kétidejü, precíziós-szituációs lenyomatot vettünk (Zetaplus, Zhermack Sga, Badia Polisina, Ravigo, Olaszország). (11. kép) Az arcíves regisztrációt és a centrális reláció meghatározását követte a vázpróba, majd a fogszínválasztás Vita 3D Master fogszínkulccsal (3M2). (12. kép) Mattpróba után a fényre égetett fogpótlás becementezésre került (3M Espe-Ketac Cem, St Paul, Minnesota, USA). (13. kép) A rövid és hosszú távú kontroll alkalmával a pácienst ismételten instruáltuk, motiváltuk a jó szájhigiéne fenntartására.

A hosszú távú kontroll alkalmával (1,5 év) a fogpótlásokon sérülés nem volt látható. 


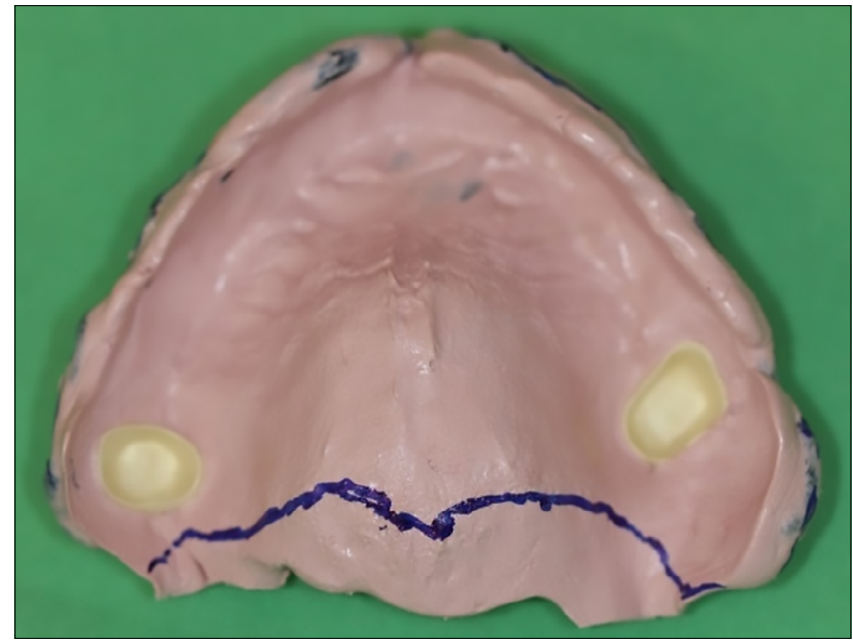

6. kép: Clear akrilát egyéni kanállal vett cinkoxid-eugenol funkciós szituációs lenyomat a primer teleszkópokkal.

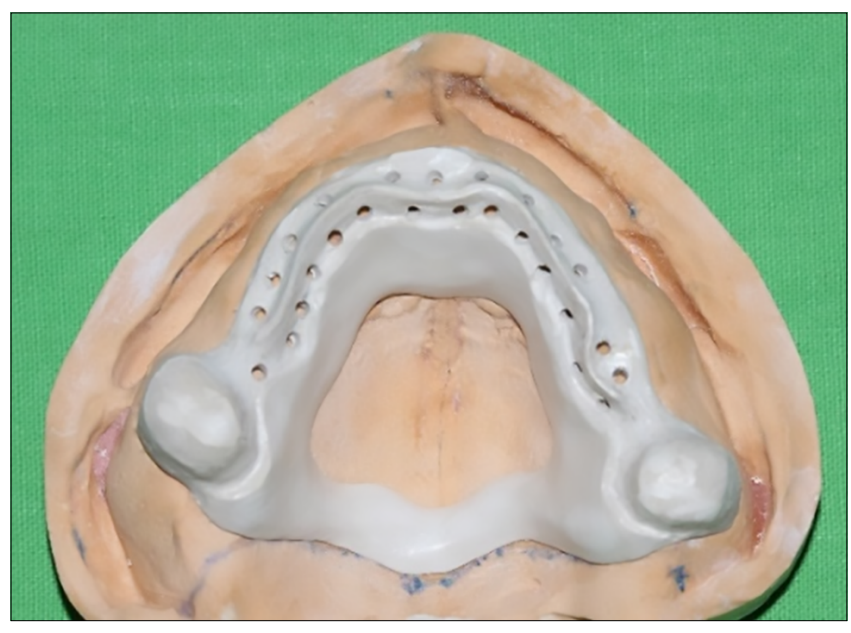

7. kép: Fenesztrált BioHpp alaplemez a mintán, az alaplemezhez ragasztással rögzített secunder teleszkópokkal.

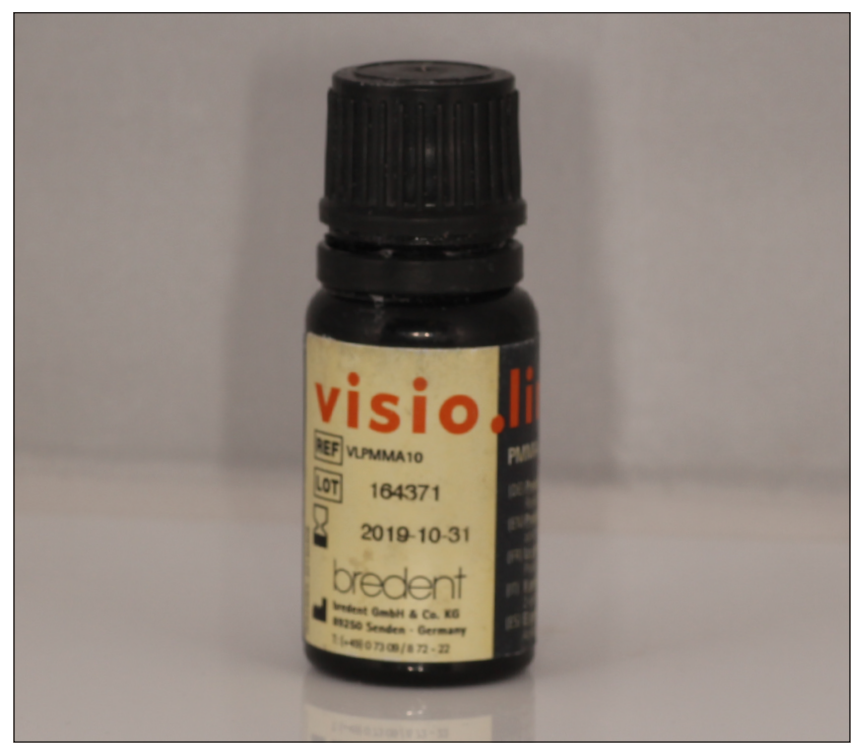

8. kép: A ragasztáshoz felhasznált Visio.Link rögzítő anyag.

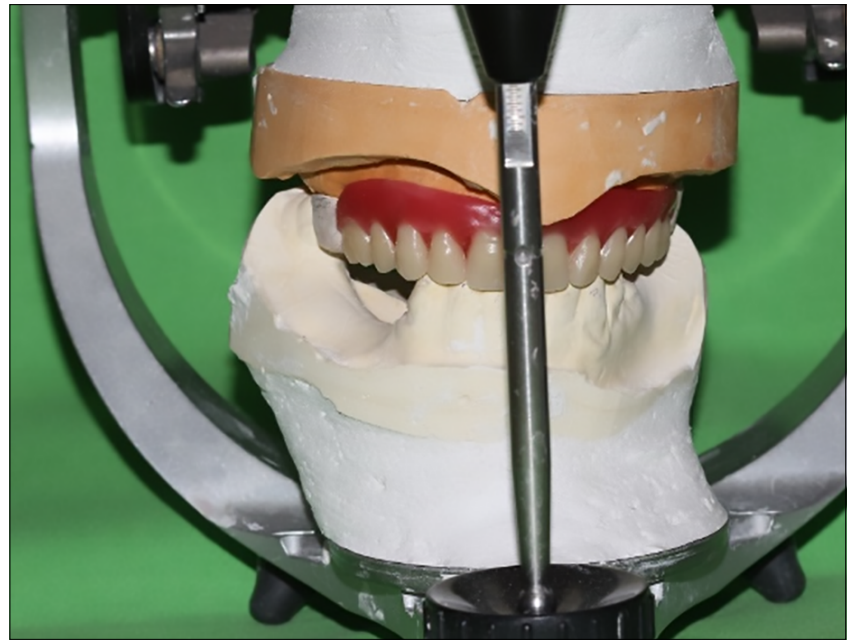

9. kép: Felső próbafogsor

Protár 5B egyéni értékủ artikulátorban.

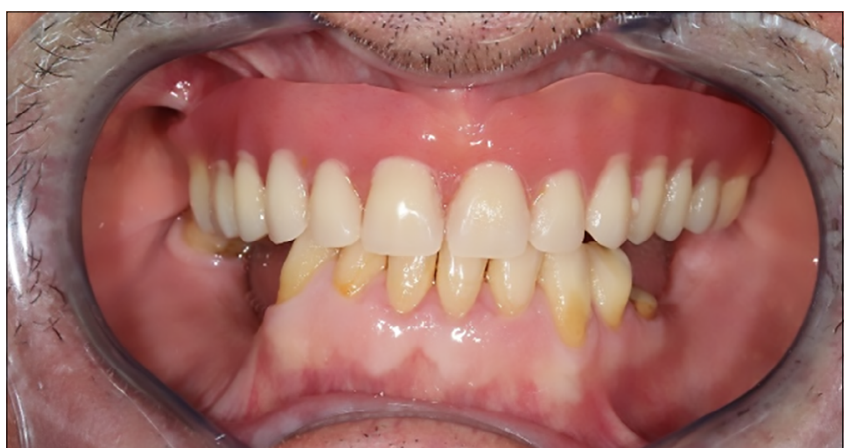

10. kép: A kész felső fogpótlás átadása.

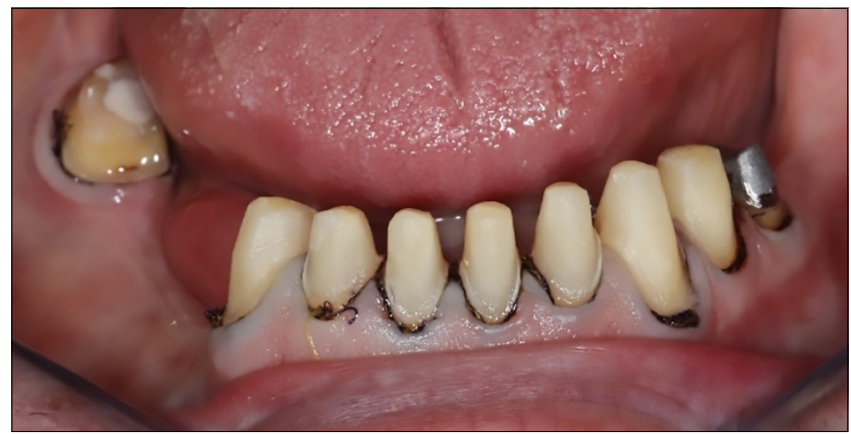

11. kép: Alsó állcsonton,

szupragingivális chamfer vállal preparált fogak.

A segédpillérek számát növeltük a GM-rohamok okozta többletterhelés kompenzálására.

A vegyi csonkvédelem Bifluoriddal történt.

\section{Összegzés}

A BioHpp alkalmazásáról kevés irodalmi adat áll rendelkezésünkre, így jelen közlemény hiánypótlónak tekinthető. Ígéretesnek látszik alkalmazása grand mal rohamozó epilepsziás betegek kivehető fogpótlással történő ellátásában, mert a müíny és müfogak alaplemezhez 


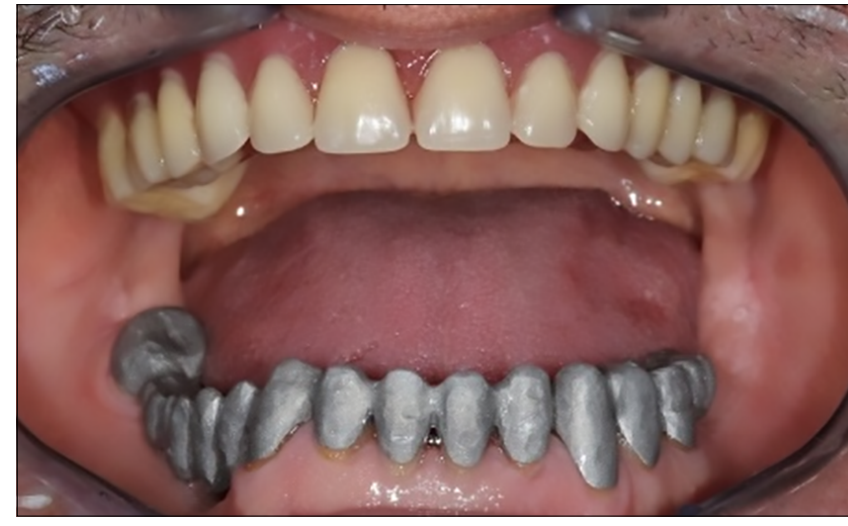

12. kép: Alsó hídváz próbája a szájban, a megerősített konnektor részekkel.

történő rögzítése mechanikai és kémiai úton is történik, ezáltal jóval erősebb, mint a hagyományos kobalt-króm alaplemezek esetében. A továbbiakban is tervezzük epilepsziás betegek kezelésekor alkalmazását. $[10,11]$

\section{Irodalom}

1. Károlyházy K, Arányı Zs, Hermann $P$, Vastagh I, Márton K: Oral Health Status of Stroke Patients Related to Residual Symptoms: A Case-Control Epidemiological Study in Hungary. Oral Health Prev Dent 2018; 16: 233-239.

2. Laidans J, Richens A, Chadwick D. (szerk.): A textbook of epilepsy. Hauser W A, Annegers J F. Epidemiology of epipepsy: 23-45. Livingstone, Edinburgh, 1993.

3. Károlyházy K, Kovács E, Kivovics P, FeJérdy P, Arányı Zs: Dental status and oral health of patients with epilepsy: An epidemiologic study. Epilepsia 2003; 44: 1103-1108. https://doi.org/10.1046/j.1528-1157.2003.04003.x

4. Károlyházy $K$, Kivovics $P$, Hermann $P$, Fejérdy $P$, Arány $Z s$ : Five year follow up of oral health and seizure condition of patients with epilepsy: A prospective observational study. Community Dental Health 2010; 27: 233-237.

5. Buck D, Baker GA, Jacoby A, Smith DF, Chadwick DW: Patients' experiences of injury as a result of epilepsy. Epilepsia 1997; 38: 439-444. https://doi.org/10.1111/j.1528-1157.1997.tb01733.x

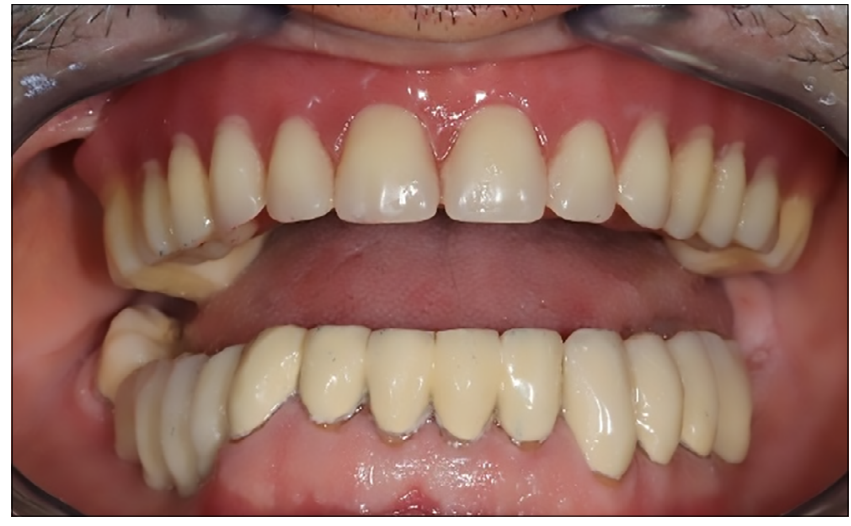

13. kép: Alsó fémvázas, kompozit leplezésú hidak átadása.

6. ZSIGMOND Á, KÁROLYHÁZY K:

Dentális trauma komplex ellátása: Esetismertetés.

Magyar Fogorvos: A Magyar orvosi kamara fogorvosi tagozatának lapja 2013; 22: 62-73.

7. Somfai D, Zsigmond Á, Károlyházy K, Kispélyı B, Hermann P: Cirkónium dioxid használata a klinikai gyakorlatban. Fogorvosi Szemle 2015; 108: 121-125.

8. Károlyházy K, Schmidt P, Bogdán S, HeRmann P, Arányl ZS: Prosthodontic treatment of an edentolous epileptic patient with an implant retained overdenture.

Clinical Neurosience 2014;67: 342-346.

9. Rо́тH L (szerk.): Fogpótlás.tan update.

4. fejezet: Shuldes S. Fémmentes és kivehető. 168-173. DP Hungary Kft. 2018.

10. Andrikopoulou El, Zoidis P, Artopoulou II, Doukoudakis A: Modified PEEK Resin Bonded Fixed Dental Prosthesis for a Young Cleft Lip and Palate Patient. J Esthet Restor Dent 2016; 28: 201-207. https://doi.org/10.1111/jerd.12221

11. Zoidis P, Papathanasiou I, Polyzois G: The Use of a Modified Poly-Ether-Ether-Ketone (PEEK) as an Alternative Framework Material for Removable Dental Prostheses. A Clinical Report.

J Prosthodont 2016; 25: 580-584. https://doi.org/10.1111/jopr.12325

12. Greene AH, Vermillion JR: The oral hygiene index - a method for classifying oral hygiene studies. J Amer Dent Assoc 1960; 61: 172-178. https://doi.org/10.14219/jada.archive.1960.0177

\section{Prosthodontic treatment of epileptic patient using BioHpp dental material}

A 65 years old patient with medical history of various therapy-resistent types of epileptic seizures, such as grand mal (GM) seizure with loss of consciousness, absence, myoclonic seizure, and complex partial seizure. The seizures resulted in numerous injuries all over his body, including but not limited to broken clavicula, broken orbital base, and dislocation of his shoulder. Due to the fractures of acrylic-made artificial teeth and artificial gingiva of the removable upper partial denture with metal base plate, the standard dental prosthesis was considered impractical for this patient. Instead, the BioHpp dental material, which is more robust and elastic than the customary materials used in removable partial dentures (CoCr, acrylic), was sourced. The epileptic patient has been using his BioHpp removable partial denture for a period of one and a half year, without any complaint. This case study may be used to support point to a novel clinical application of BioHpp in treating epileptic patients with removable partial dentures.

Keywords: epilepsy, BioHpp, GM seizures 